\title{
What to do for the exposed end of a K-wire?
}

\section{K-telinin serbest ucu için ne yapılabilir?}

\author{
Oğuz KAYIRAN ${ }^{1}$, Ahmet Duran KARA ${ }^{2}$
}

\section{SUMMARY}

$K$-wire is mostly used for bone fixation, but the protection from the exposed end of the wire may be problematic. Numerous methods have been proposed for the protection from the free end of the K-wire. Although most of them seem to be practically used techniques, they have not been completely described yet. This article reveals simple and easy methods for the management of the free end of a K-wire by making various explanations. For this purpose, bending, taping, blood sampling tube caps, butterfly needles, needle hubs and rubber gaskets were used for the exposed end of the $K$-wires. The patients' comfort scores were assessed. Taping was accepted as the most comfortable method to secure the wire end.

Key words: $K$-wire, exposed end, management, phalanx, fracture
ÖZET

K-teli çoğunlukla kemik fiksasyonu için kullanılmakta ancak serbest ucundan korunmak sorunlu olabilmektedir. Korunma amacıyla birçok yöntem kullanılmaktadır. Her ne kadar çoğunluğu pratik teknikler olarak görülmekteyse de tanımsal açıklamaları bulunmamaktadır. Bu makale, çeşitli teknikleri ortaya koymakta ve açıklama getirmektedir. Bu amaçla, bükme, bantlama, kan tüpü başlığı, kelebek iğneleri, soketler ve kauçuk contalar kullanılmıştır. Hastaların konfor skorları değerlendirilmiştir. Bantıama en konforlu yöntem olarak görülmüştür.

Anahtar kelimeler: K-teli, serbest uç, tedavi, falanks, kırık

\section{INTRODUCTION}

The desired positioning of fractured bone ends with appropriate reduction of the fracture is carried out with meticulous pinning. However, after the fixation, the cut end of the wire is a challenging problem for the practitioners. This exposed end may get stuck to the surrounding tissues and when left unattended, the sharp end can cause trauma and even devastating ocular injury ${ }^{1}$. The exposed end can be cut very short; however the removal will require an additional procedure. There are not many options for the protection of an exposed end of a K-wire whereas the materials such as adhesive tape, corks, rubber stoppers, epoxy putty, tip caps, balls, and plastic or rubber gaskets are in practical use by the physicians ${ }^{1-3}$. In addition, the cut end of the wire can be bended backwards fully. This technique does not need any material; however it may not be easy to flex thick wi- res. Mainly, the practitioner will choose among these methods. In our current study, we combined the present methods with new adapted ones as well.

\section{MATERIALS and METHODS}

Between April and September 2009, 36 patients were operated for various indications by using K-wires. The ages of the patients ranged from 3 to 75 years (median: $32.25 \mathrm{yrs}$ ). For the cut end of the wires, plastic or rubber gaskets, needle hubs, blood sampling tube caps, taping or bending techniques were used. The methods used for this purpose and the distribution of the patients are summarized in Table 1. Bending was carried out solely in the thin K-wires for the ease of the technique. The remaining materials were blindly chosen by the surgeons.

The patients were followed up for 1 year. Within the

Received: 25.06.2015

Accepted: 04.07.2015

${ }^{1}$ Kolan Hastanesi, Plastik ve Rekonstrüktif Cerrahi Kliniği

${ }^{2}$ Reyap Hastanesi, Ortopedi ve Travmatoloji Kliniği

Yazışma adresi: Op. Dr. Oğuz Kayıran, Kolon Hastanesi Plastik ve Rekonstrüktif Cerrahi Kliniği, Darülaceze Caddesi, Şişli, İstanbul

e-mail:droguzk@yahoo.com 
second postoperative week, the patients were asked to fill in a questionnaire to clarify if he or she was satisfied with the vision of the selected option. In addition, we wanted the patients to give a score from 1 (not satisfied) to 5 (most satisfied) to assess the comfort of the technique. The score of three and more was accepted as successful management.

\section{RESULTS}

25 patients (69.4\%) were male, and the remaining 11 (30.6\%) were female. 9 bending was made, 8 blood sampling tube caps, 5 rubber gaskets, 4 needle hubs, and 3 butterfly needle parts were used. Taping was preferred to cover the exposed ends of $38 \mathrm{~K}$-wires. All selected techniques and materials were used until the permanent removal of the K-wires. No complications were noted with regard to the selected techniques.

Ninety-six of the male and $72.7 \%$ the female patients were satisfied with the procedure. In other words, $88.9 \%$ of all the patients were satisfied. Among 36 patients, $25 \%$ of them gave the highest comfort score, whereas $2.8 \%$ gave the least. The distribution of the scores can be clearly seen in Table 1 .

Among all techniques, the highest comfort score was noted in taping. Meanwhile, higher comfort scores (comfort score 4 and 5) were observed in the patients where blood sampling tube caps and bending

Table 1. The distribution of the patients according to age, gender, diagnosis, selected techniques and comfort scale.

\begin{tabular}{|c|c|c|c|c|c|}
\hline No & Age & Gender & Diagnosis & Technique selected & Comfort score \\
\hline 1 & 29 & M & Subacute Butonniere deformity of $3^{\text {rd }}$ finger & Bending & 4 \\
\hline 2 & 30 & M & Distal phalanx fracture of $4^{\text {th }}$ finger & Rubber gasket & 5 \\
\hline 3 & 12 & M & PIP joint dislocation with proximale phalanx fracture of $4^{\text {th }}$ finger & Rubber gasket & 4 \\
\hline 4 & 29 & $\mathrm{~F}$ & PIP joint dislocation with proximale phalanx fracture of $5^{\text {th }}$ finger & Needle hub & 4 \\
\hline 5 & 40 & M & Swan-neck deformity of $5^{\text {th }}$ finger & Taping & 4 \\
\hline 6 & 26 & M & PIP joint dislocation with proximale phalanx fracture of $2^{\text {nd }}$ finger & BSTC & 3 \\
\hline 7 & 29 & M & Chronic Butonniere deformity of $4^{\text {th }}$ finger & Bending & 4 \\
\hline 8 & 33 & M & Acute mallet finger of $2^{\text {nd }}$ finger & Butterfly needle & 4 \\
\hline 9 & 61 & M & Metacarpal fracture of $1^{\text {st }}$ finger & BSTC & 4 \\
\hline 10 & 30 & M & Subtotal amputation of $3^{\text {rd }}$ finger & Bending & 3 \\
\hline 11 & 24 & $\mathrm{~F}$ & Acute mallet finger of $5^{\text {th }}$ finger & Needle hub & 5 \\
\hline 12 & 28 & M & High-current electrical injury (For wrist artrodhesis) & Taping & 2 \\
\hline 13 & 41 & $\mathrm{~F}$ & Swan-neck deformity of $3^{\text {rd }}$ finger & Bending & 5 \\
\hline 14 & 53 & $\mathrm{~F}$ & Spontaneous EPL tendon rupture in RA patient & Butterfly needle & 4 \\
\hline 15 & 40 & M & Middle phalanx fracture of $5^{\text {th }}$ finger & Needle hub & 4 \\
\hline 16 & 36 & M & Metacarpal fracture of $1^{\text {st }}$ finger & BSTC & 5 \\
\hline 17 & 17 & M & Swan-neck deformity of $2^{\text {nd }}$ finger & Butterfly needle & 4 \\
\hline 18 & 27 & M & Subtotal amputation of $2^{\text {nd }}$ finger & Bending & 3 \\
\hline 19 & 37 & M & PIP dislocation of $3^{\text {rd }}$ finger and middle phalanx fracture of $4^{\text {th }}$ finger & 2 taping & 4 \\
\hline 20 & 31 & M & MP joint dislocation of $5^{\text {th }}$ finger and metacarpal fracture of $4^{\text {th }}$ finger & 2 rubber gaskets & 4 \\
\hline 21 & 28 & $\mathrm{~F}$ & Hallux valgus deformity & Taping & 2 \\
\hline 22 & 35 & M & Proximal phalanx fracture of $1^{\text {st }}$ finger & BSTC & 4 \\
\hline 23 & 42 & M & Middle phalanx fracture of $2^{\text {nd }}$ finger & BSTC & 5 \\
\hline 24 & 3 & M & Fracture of transconydler humerus & Bending & 4 \\
\hline 25 & 46 & $\mathrm{~F}$ & Hallux valgus deformity & Bending & 1 \\
\hline 26 & 40 & $\mathrm{~F}$ & Traumatic EPL rupture & BSTC & 2 \\
\hline 27 & 33 & M & Middle phalanx fracture of $3^{\text {rd }}$ finger & Bending & 4 \\
\hline 28 & 5 & M & Fracture of transconydler humerus & Taping & 5 \\
\hline 29 & 41 & M & Fracture of medial malleolus & BSTC & 4 \\
\hline 30 & 13 & M & Middle phalanx fracture of $2^{\text {nd }}$ finger & Taping & 5 \\
\hline 31 & 44 & $\mathrm{~F}$ & Swan-neck deformity of $4^{\text {th }}$ finger & Rubber gasket & 4 \\
\hline 32 & 45 & M & Dislocation of talocalcanear joint & Bending & 5 \\
\hline 33 & 11 & M & Gustilo type 1 fracture of tibia & BSTC & 4 \\
\hline 34 & 75 & $\mathrm{~F}$ & Fracture of radius & Taping & 5 \\
\hline 35 & 7 & $\mathrm{~F}$ & Montegio fracture & Taping & 3 \\
\hline 36 & 40 & $\mathrm{~F}$ & Chronic Butonniere deformity of $5^{\text {th }}$ finger & Needle hub & 4 \\
\hline
\end{tabular}

M: Male, F: Female, PIP: Proximal interphalangeal, BSTC: Blood sampling tube cap, MP: metacarpophalengeal, EPL: Extensor pollicis longus, RA: Romatoid arthritis. 
were used. However, these findings were not statistically significant.

\section{DISCUSSION}

K-wires are used for various reasons. It is well known that great care must be taken during their insertion to avoid inadvertent damage to adjacent structures. Simple methods are demonstrated to diminish the soft tissue damage ${ }^{4-6}$. However, not only the insertion of the K-wire but also the free end of the wires can be problematic for the patients. Meanwhile, the literature gives us little data how to secure the free end of a $\mathrm{K}$-wire. One of the techniques is percutaneous K-wire fixation to the finger skin for the exposed ends ${ }^{7}$.

The physicians use variable options for the protection of the secured end of K-wires based on their preferences. Mostly, the options available for this purpose are utilized practically. In practice, numerous options with various materials can be found worldwide with great ease of access.

In the market, standard disposable needles include a plastic luer lock hub, with a stainless steel cannula (or tubing) based on gauge size. Non-sterile needles with caps are generally used for mechanical or electronical purposes. However, sterile needles are mostly observed in the medical area. With the developing era, sterilization techniques have been extremely improved, meaning that the non-sterile needle packages are distributed worldwide.

Owing to the developing medical systems worldwide, the boiling traditions were entirely changed, and disposable sterile products for single use such as syringes have been utilized. When we look at the

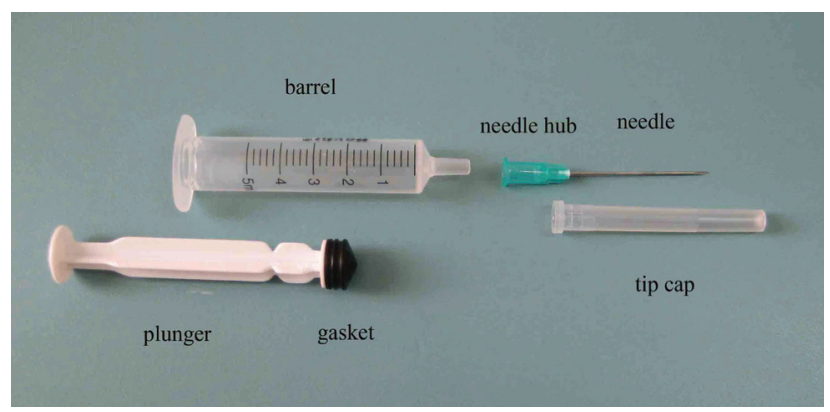

Figure 1. The anatomy of a syringe. Please note that a $5 \mathrm{ml}$ syringe with a 21 gauge needle (green hub) is demonstrated here. components of the syringe, two separate pieces were noted as the needle with tip cap and the luer with the forcer and the plastic or rubber gasket (Figure 1). Meanwhile, tip caps, gaskets, and needle hubs can be inserted through the cut end of the K-wires.

The materials that can be used for the free-end of $\mathrm{K}$-wires are described as follows.

Needle hub: This method seems practical, simple, easy, cheap and can be found everywhere around. In practical use, we found different needles, either sterilized or not, with different hubs which were produced in gauge units. When the hubs were separated from its needle, the gap of the present needle hub enables an easy insertion to the cut end of the K-wire (Figure 2). There are several needles and needle hubs of various sizes in the market that can be used ${ }^{8}$. The hubs are produced according to the dimension of the needle. For this reason, various kinds of hubs are available. However, the growing industry enabled the production of new needle hubs with or without scabbards. These kits enabled the physicians to use them with an increased cost-effectiveness.

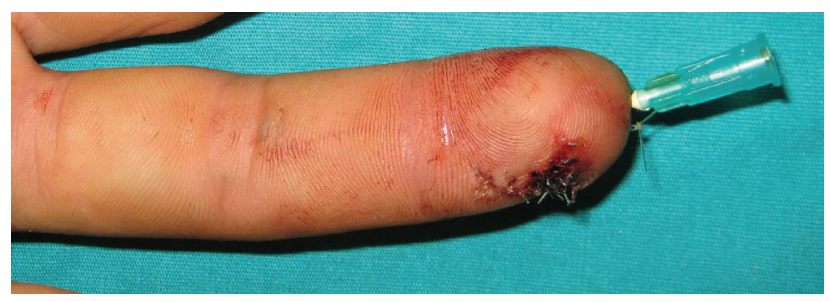

Figure 2. A needle with its hub was inserted to stabilize the fracture.

Plastic or rubber gasket: When a syringe is opened from its sterile package, the gasket can also be used like the needle hub of the needle. This method is more preferable when the reduction and the fixation of the fracture are carried out under problematic and hard conditions. The practitioner must acknowledged that the rubber can be attached and detached easily from the distal end of the wire.

Blood sampling tube cap (BD Vacutainer ${ }^{\circledR}$ ): Blood sampling tube cap (BSTC) was developed in 1947 by Joseph Kleiner, and is currently marketed by Becton, Dickinson and company ${ }^{9}$. They are produced in various measures. The cap of the tube that is produced in plastic with rubber inside can be used preferably (Figure 3). 
Taping: Taping the free end of the wire is a simple method of the choice, but the most undesired side effect seems that the tape may slip away. However, it is cheap and does not occupy much space at the free end unlike the others.

Bending: Bending the most distal end of the wire may be the widespread preferred method in order to secure the cut end from the environment. With this, there is no need for an additional equipment or tool. But, bending itself has some disadvantages like the difficulty of the technique, and the possibility of impairing the desired reduction. In addition, with the developing skill of the surgeon, the bending will be more admiring within the theatre (Figure 3 ).

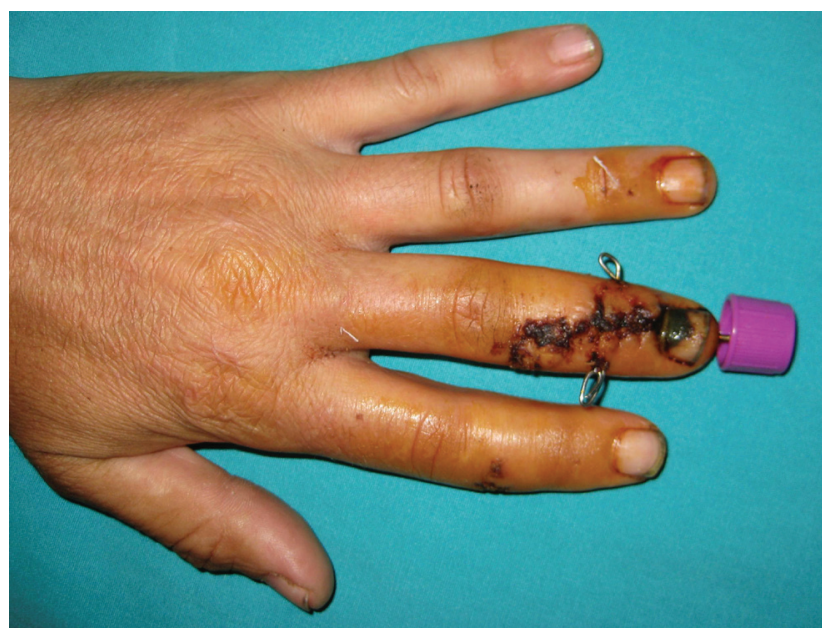

Figure 3. Blood sampling tube cap was used to secure the exposed end of a k-wire. Please note that bending was also performed to another $\mathrm{K}$-wire on the same finger.

Butterfly needle: Separate components of the butterfly needle can be used to cover the exposed end of the needle.

Epoxy putty: This method was not preferred in our patients. However, in the literature, it was found that the epoxy putty was predominantly used in veterinary orthopedics ${ }^{10}$.

Comfort score, though, is a subjective marker to assess the satisfaction, it gives a better idea to the physician if the technique is favorable or not. To us, five different scores indicated the transition characteristics of the patients' perception of the vision. However, to analyze this, more factors are needed. Thus these variables will enable to clarify more clear and statistically significant results.

When the physicians use K-wire for several reasons, they usually neglect the free end of the wire. This cut end annoys mostly the patient.

In this manner, the reasons for choosing the selected material by the practitioner are:

1. to prevent the K-wire from harming surrounding structures,

2. to give a better image and provide the most comfortable postoperative period to the patient,

3. to make a decision about what can be done for the security of a free end of a K-wire in sterile conditions.

This study revealed the fact that the free end of a K-wire shall be secured either to give a better image or to increase the comfort of the patient. In addition, the practitioner, henceforth, can choose among the methods discussed in this article.

\section{REFERENCES}

1. Lenin Babu V, Kumar P, Paul A. A simple K-wire cap. Acta Orthop Belg 2005; 71: 610-1.

2. Hu JW, Jung SN. A simple method for K-wire capping using nelaton rubber catheter. Indian J Plast Surg 2009; 42: 132-3. http://dx.doi.org/10.4103/0970-0358.53027

3. Vishwanath G. Managing the cut end of a K-wire. Ind J Plast Surg 2010; 43: 117-8.

http://dx.doi.org/10.4103/0970-0358.63943

4. Matteucci P, Majumder S, Southern SJ. Tissue protection when using K-wires in the hand. Br J Plast Surg 2004; 57: 180-1.

http://dx.doi.org/10.1016/j.bjps.2003.11.004

5. Hochwald NL, Levine R, Tornetta P. The risks of Kirschner wire placement in the distal radius: a comparison of techniques. $J$ Hand Surg [Am] 1997; 22: 580-4. http://dx.doi.org/10.1016/S0363-5023(97)80112-8

6. Stahl S, Schwartz O. Complications of wire fixation of fractures and dislocations in the hand and wrist. Arch Orthop Trauma Surg 2001; 121: 527-30.

http://dx.doi.org/10.1007/s004020100279

7. Barth AH, Colgrove RC. Percutaneous K-wire fixation: protection of the exposed end. J Foot Ankle Surg 2002; 41: 197-8. http://dx.doi.org/10.1016/S1067-2516(02)80072-2

8. www.dispensinglink.com/Half\%20Inch $\% 20$ Dispensing $\% 20$ Tips.htm.

9. Rosenfeld L. A golden age of clinical chemistry: 1948-1960. Clin Chem 2000; 46: 1705-14.

10. De La Puerta B, Emmerson T, Moores AP, et al. Vet Comp Orthop Traumatol 2008; 21: 451-6. 